\title{
Environment as an Element of Development: The Growing Role of Energy Efficiency and Environmental Protection in Chinese Economic Policy
}

\author{
Deborah Seligsohn
}

The developmental issues at the core of this book are fundamental to China's discussions of what the country has achieved over the past three decades of reform and opening and where policy makers believe society and the economy need to go in the future. Economic growth has been at the center of China's development agenda since 1949 (Brandt and Rawski 2008), although the approach to economic growth shifted radically. The reforms unleashed by Deng Xiaoping, starting in 1979 and then accelerating in 1992 are widely credited with economic growth averaging almost 10 percent a year for the entire period since $1980 .{ }^{1}$ Moreover, the Chinese government has particularly prided itself on raising hundreds of millions from abject poverty during this period, an achievement that has been widely recognized by the international development community (Ravallion and Chen 2005).

Throughout the 1980s and the 1990s, there was a broad consensus that an economic policy focused primarily on economic growth met China's most urgent needs (Naughton 2008). One of these was clearly poverty alleviation, and the assumption was that a bigger pie would ensure more for those at all levels of society. But it was hardly the only goal. The Chinese government has always had a major political agenda, both in terms of stability at home and security internationally, and delivering economic growth has been seen as central to both. Domestically, prosperity has tended to keep the public satisfied and maintain cohesion within the Chinese Communist Party (CCP), while from an international security point of view, it has given China both a stronger military and more negotiating leverage in a variety of fora. 
But as China has become wealthier, perceptions of its development needs among the general public, within the leadership, and within the broader governmental bureaucracy have shifted, become broader, and more nuanced. At its current stage of development, the need to address the other development issues raised in this book-structural change and environmental degradation-are both widely recognized. Both issues are prominent in the 12th Five Year Plan, China's governing national policy document outlining the major directions in economic planning over the period, 2011 through the end of 2015. These new concerns have not replaced the previous focus on economic growth and social stability, but have been added to the development agenda. Poverty alleviation still continues to be a goal, and indeed international interlocutors are likely to hear from their Chinese partners that China is still a poor country with urgent poverty alleviation needs. However, poverty alleviation has to a significant extent been reframed as requiring income redistribution and social service provision in addition to growth (Wong 2009). These goals are centered by a focus on the "quality" of economic growth that also includes environmental protection.

This chapter focuses on how environmental protection has developed into a meaningful part of this overall program of development. Environmental protection has moved from being a goal that observers both inside and outside China perceived as mere window-dressing to a fundamental national goal that local governments take seriously and where there are measurable national results.

\section{The Costs of Pollution}

China has suffered the environmental consequences of rapid development with poor environmental regulation for decades. ${ }^{2}$ Environmental quality was poor even before China began its period of rapid growth and industrial expansion with its reform and opening policies in 1979. By the time China began to grow rapidly, attitudes stemming both from its communist central planning past and its developing country status led to considerable disregard for environmental issues for a number of years.

The first major study to document the impact of pollution on the Chinese populace was the World Bank's Clear Water, Blue Skies report in 1997, which estimated environmental damage to cost China 8 percent of GDP, while estimating 178,000 premature deaths annually in major cities from outdoor air pollution and 110,000 in rural areas from indoor air pollution. More recent estimates of health impacts have been higher, while the GDP percentages have tended to be lower. These indicate considerable improvements in data scope and quality, although data issues remain. The widely cited ${ }^{3}$ World Health Organization's 2009 China Country Profile of the Environmental Burden of Disease estimated 299,400 deaths per year from outdoor air pollution and 548,900 from indoor air pollution out of a total of 2.4 million environmental health deaths annually. ${ }^{4}$ The most widely known and still the most controversial effort to quantify the impact of environmental damage 
was the World Bank's 2007 study "Cost of Pollution in China; Economic Estimates of Physical Damages," a document that was released in a conference edition, but never in final form. The study offers wide ranges for its estimates of premature deaths, with, for example, the mean estimates of deaths from outdoor air pollution ranging from 110,000 to 394,000 per year, depending on the methodology used. The more often cited GDP cost estimates that have appeared to be at the center of the controversy are also given with a broad range of 2.7 percent to 5.8 percent of GDP, with the press at the time widely citing figures in the 3 percent range. The GDP costs considered not just health impacts, but also other pollution-related damage, including crop and natural resource losses and infrastructural damage.

The World Bank's health estimates were based on a dose-response approach that is supported by the work of the US-based Health Effects Institute (HEI), whose 2004 study, updated in 2010, Outdoor Air Pollution and Health in the Developing Countries of Asia: A Comprehensive Review (HEI 2010) evaluates the existing studies on health impacts in China, along with other countries in developing Asia. The HEI survey of existing data shows that the health impacts from air pollution in Asia are broadly similar to those in the United States and Europe. A critical insight of the HEI survey is that the health effects are dose-related, and thus incremental reductions in the level of air pollution have demonstrable results in improving human health. While these studies all cite health figures going back half a decade or more-generally from before China's major effort to improve environmental quality - we can use this dose-related insight to infer that the improvements that have occurred since 2006 are positive for human health in China.

While the damage of pollution extends well beyond health, the converse is also true: much of what affects overall environmental health is not related to modern air or water pollutants. All of the studies above note that Chinese environmental health is in fact improving, and much of this is due to the control of more traditional sources of environmental disease, primarily poor water and sanitation. Indeed, in recent years, both the World Bank and the WHO have focused on China's non-communicable disease (NCD) burden, as China has already made considerable progress in controlling many of the infectious diseases that disproportionately affect the world's poor. While pollution is one cause of NCDs, the World Bank's 2011 report, "Toward a Healthy and Harmonious Life in China: Stemming the Rising Tide of NonCommunicable Diseases," briefly mentions pollution as a cause of NCDs and recommends enforcing pollution law and regulations, but these are not the priority interventions. The larger causes of NCDs in China are primarily behavioral - with tobacco, salt, and alcohol intake topping the list.

Indeed, it is worth keeping in mind Kirk Smith's admonishment in his discussion of environmental health in China that environmental quality and environmental health are not always closely linked, "just because something is outrageous does not mean it is particularly unhealthy" (Smith 2008). Smith's point is that environmental health impacts relate closely to dose and exposure. Thus, for example, occupational exposure is often more deadly 
in both developed and developing countries, and yet more focus is generally placed on ambient exposure of the general population. Smith has also been a leader in pointing out the impact of indoor air pollution, and it would be fair to surmise that estimates of the health impact of indoor pollution have risen steadily in China not because there are more farmers with old-fashioned cook stoves (commercial fuel has grown rapidly over this period), but because the issue is better understood. But we can also look at his analysis to realize that health impacts, while widely cited in most of the literature, are just one of many reasons the public wants to see pollution issues addressed.

Indeed, public concern in China can hardly be related to any knowledge of health impacts, which are not well covered in the Chinese press. As the title of the World Bank's original study "Clear Water, Blue Skies" makes clear, environmental quality is valued for itself as well as for its additional benefits. Public discussion of pollution in China is not generally tied to these specific health or economic outcomes-improvements are measured on their own terms. While this can be interpreted as a weakness of analysis, it may also reflect a conviction that environmental improvements are obviously good and do not need further justification.

\section{Changing Attitudes}

Attitudes toward environmental protection have changed dramatically in the past decade, and results are starting to be demonstrable on the ground. Energy efficiency and environmental protection have moved from the periphery to recognition as central issues in Chinese government policy, highlighted in Five Year Plans and major policy speeches. Provinces are under pressure both from the central government and the general public to produce results, and in the past six years they have done so. The 11th Five Year Plan (2006-2010) was the first five-year plan in which a pollution reduction target (sulfur dioxide, $\mathrm{SO}_{2}$ ) was met, and in fact exceeded. Moreover, China also came close to meeting its goal to reduce energy intensity (energy used per unit of GDP generated) by 20 percent. $^{5}$ This was particularly striking when contrasted with the first half of the decade (the 10th Five Year Plan period), when most indicators deteriorated considerably, including energy intensity which had been improving steadily in the 1980s and the 1990s.

When we look at the major indicators the Chinese government focused on, in particular energy intensity and $\mathrm{SO}_{2}$ emissions, 2006 appears as a clear inflexion point. Energy intensity had been gradually improving for decades, but actually rose in the early 2000s. With the inception of the 12th Five Year Plan, energy intensity began to improve, and despite considerable challenges over the five-year period, particularly the global economic crisis and China's massive stimulus spending, overall energy intensity was almost 20 percent lower at the end of 2010 than it had been at the beginning of 2006. Moreover, $\mathrm{SO}_{2}$ emissions, where the goal was a 10 percent reduction, had actually fallen more than 14 percent during the same period. 
Clearly a change occurred, but how did it happen? The challenges posed by pollution and high-energy intensity were well known for decades. But a confluence of political, economic, and institutional developments has changed the priority for action and the government's capacity to act.

\section{Energy Security}

Energy security has been one of China's major historic concerns, going back at least as far as the Sino-Soviet split in the late 1950s/early 1960s, when China was left without a stable supply of imported oil (Calder 2005). While China had been self-sufficient in coal for centuries, it relied heavily on imported oil for the first decade of the new People's Republic. This changed when the Soviet advisors pulled out and China's import source disappeared. The fortuitous discovery of one of the world's largest oil fields at Daqing in Heilongjiang in the early 1960s, just after the Sino-Soviet split, rescued China from an energy crisis. It also paved the way for decades of energy independence, and established itself as one of modern China's great narratives of self-reliance (Andrews-Speed and Dannreuther 2011).

Later oil finds were not nearly as large as Daqing. As the economy grew and Daqing's own reserves were being depleted, it became clear by the early 1990s that China was soon to become a net oil importer. In fact, China became a net importer in 1993, even though publicly delays and corrections in data meant that policy makers were not fully aware of the watershed for a year or two. Analysts had expected this change in trading position to be a major concern for the Chinese government, but in the event the change was barely remarked upon and caused little change in Chinese government policy.

China became a net importer of oil during a period of stable global prices, and energy security slipped to the back burner. This began to change in the 2000 s, as energy prices became unstable, political instability in source countries became more apparent, and potential conflict with other consumer countries also became a greater concern. A confluence of events in 2005 brought this message home. The first was the run-up in world oil prices and Chinese imports in 2004. Chinese imports rose particularly rapidly during that year, and while they later slowed down, significant international media attention in 2005 focused on Chinese imports as a cause of higher oil prices. Moreover, there were two votes in the US House of Representatives in 2005-one on the import of nuclear equipment and the other on a proposed purchase of a US oil company (UNOCAL by CNOOC) that made Chinese policy makers nervous. While neither vote was binding, both suggested that there was some opposition to China's efforts to secure its energy supplies internationally.

At the same time, China became increasingly concerned about security of supply, even from domestic sources. Heavy dependency on coal from a single region left China very vulnerable to natural disasters, such as the blizzards of 2008 (French 2008). The net result of these energy security issues was 
to bring back energy efficiency programs that had lain dormant since the late 1990s. Controlling the rapid rise in China's energy demand was clearly beneficial all around-it reduced the need to turn to international markets, it reduced the pressure on China's own supply lines, and it saved money. Similarly developing nonfossil energy sources reduced competition for foreign energy supplies and diversified supply within China, reducing pressure on the coal transport system (Naughton 2005).

\section{New Wealth and a Broader Notion of Development}

The early 2000s were in many ways a watershed period for China's worldview and economic development. China joined the WTO in 2001. Negotiating entry and preparing the economy for this transformation had preoccupied much of Chinese economic and trade policy as well as international diplomacy throughout the 1990s. Now China could reap the benefits (Dollar and Kraay 2003). And these benefits turned out to be considerable. Growth averaged 10.5 percent in the decade 2001-2010 (World Bank), and while the full ten-year average had been the same in the 1990s, in fact, over the course of the 1990s growth had slowed, while in the 2000s it accelerated for much of the decade. The net result of this cumulative rapid growth, extending back to when China initiated reforms in 1979, was that China was vastly richer than it had been just two decades earlier, and by 2005 , it was much wealthier than it had been even in the late 1990s. An economy growing at 10 percent a year doubles its size every seven years: thus when China looked at its next five-year plan in 2005 , it was more than twice as wealthy as when it had founded its first environmental enforcement agency, the State Environmental Protection Administration (SEPA) in 1998.

Hand in hand with greater wealth, China had gained considerably in institutional capacity. In the lead-up to the accession to the WTO, there was considerable debate about how accession would affect the Chinese economy, with large claims of benefits as well as concerns about the short-term costs of restructuring. While there were a number of estimates of these costs at the time, since then most commentators have been content to point to China's healthy growth rates of GDP and trade as signs of the success of accession. It is, however, not clear whether China's growth after 2000 was due directly to increased trade generated by accession to the WTO, by the institutional developments that were required to meet WTO entry requirements, or by the institutional reform that was simply part of China's domestic reform agenda. Lee Branstetter and Nicholas Lardy (2006) see all three elements as essential and intertwined. They make the case that China's growth in the 2000s was due both to WTO accession and to reforms in the late 1990s, and that WTO accession was a deliberate part of the reform program of the late 1990s. The Chinese central government, along with the StateOwned Enterprises (SOEs), was completely overhauled in the late 1990s. As Branstetter and Lardy argue, reformers led by Premier Zhu Rongji believed 
that his restructuring was essential to modernizing the Chinese economy. The drive was thus domestic, but WTO accession was a useful tool for getting more reluctant reformers on board.

Reform changed not just the economy, but the government structure as well. The central government and the SOEs laid off tens of millions of workers in the late 1990s. While the majority of these employees came from the much larger SOEs, the result for government and SOEs were much leaner and tighter administrations. In most (but not all) cases, ${ }^{6}$ the result was much more effective bureaucracies. While WTO accession has become a shorthand way to describe a number of very different processes-opening to trade, harmonization with international standards and practices, government reform, SOE reform, domestic regulatory reform - there is considerable debate about which contributed in what proportion to the growth rate. From the point of view of their influence on energy and environment policy, it is the sum total of these changes that matters.

This reformist period led to a positive feedback loop of greater institutional confidence and a broader definition of development. As the government and the public felt richer and better able to address additional challenges, the understanding of development expanded. And institutional reforms, whether driven by WTO accession or domestic imperatives, made it possible for the government to address these new development issues, because there was greater confidence in the ability of the government to implement policy and adapt institutions.

This confidence was strengthened and its relevance to social issues made more explicit in the wake of the 2003 SARS crisis. It seems almost forgotten now that President Hu Jintao and Premier Wen Jiabao came to power in the middle of the global panic over SARS, and that there were real fears that SARS could become a global pandemic and a long-term threat to Chinese public welfare and the Chinese economy. The epidemic was already raging in Southern China, Hong Kong, and much of Southeast Asia; the virus had yet to be identified; and on the day President $\mathrm{Hu}$ was sworn in, Canada reported its first eight cases. Just a month later, the city of Beijing virtually shut its doors to focus on SARS eradication. ${ }^{7}$ Remarkably, by July 5,2003 , the WHO had removed all travel warnings from SARS-affected areas, and the disease apparently had been removed from the human population. The effort to achieve this result was extraordinary, involving government and public mobilization, a rapid ramp up in public health capacity, and extensive international cooperation (Chan et al. 2010). This brief epidemic cost China 0.5 percent of GDP, but it cost harder hit Hong Kong a full 4 percent (Bekedam 2003). Had the epidemic not been contained so rapidly, the risk in lost lives and livelihoods would have been even greater. The epidemic thus brought home to the Chinese leadership that social issues could rapidly and adversely affect development, and that China had the institutional capacity to address these issues. The public health infrastructure moved forward rapidly in the wake of SARS, taking on other challenges, including HIV/AIDS and avian influenza. 
But neither the lessons nor the conclusions were restricted to public health. As they faced down SARS, Hu and Wen were also confronted by a public firestorm over the death of a college graduate named Sun Zhigang, who was detained and beaten in a migrant detention facility in Guangdong Province the day after Wen was sworn in. While the migrant detention facilities and their abuses had long been criticized by legal reformers and migrant advocates, middle-class urbanites were galvanized by a story about a middle-class professional in the way they had not been by the plight of ordinary workers. Strikingly, the State Council under Premier Wen Jiabao moved quickly to reform the entire system, not just try to address a smaller subset of cases. The story first surfaced April 25, and by June the central government had eliminated mandatory detention for residency reasons (Shirk 2010).

Through the 1990s the government consensus had been that economic growth was not only the primary goal, but also the only domestic social or economic policy goal. ${ }^{8}$ The argument was that there simply were not enough resources for a broader focus. The new government in 2003 dramatically altered the range of possibilities, rapidly initiating new policies in areas ranging from health to public safety, and implementing them at the provincial and local level. This change reflected a growing sense of government capacity and institutional capability, greater wealth and thus economic resources to spend on new priorities, and the interests of the public. Both SARS and the Sun Zhigang case directly affected the middle class and spoke to their anxieties. Having reached a certain level of prosperity, the urban public was much more aware of risks of losing it all-whether by entering a hospital and walking out with a poorly controlled disease or being picked up on the street in a case of mistaken identity. The middle class was expressing its desire for a higher, safer quality of life, and in the early 2000s the government showed much more awareness of these concerns and responsiveness to them.

\section{A Clean Environment as a Development Goal}

As the notion of development broadened to include both public health and quality of life, it would seem likely that environmental issues would become part of the package. But in 2003 and 2004, environmental issues and poor enforcement still seemed like back-burner issues. But by 2005 , a number of factors increased governmental attention to the stressed state of China's environment. The first was, as discussed above, renewed interest in energy policy. The best approaches to energy security—energy efficiency and diversification of supply-have obvious environmental co-benefits that advocates could highlight.

But the transforming event (Liu 2006) was the November 13, 2005, Songhua River spill - a major environmental incident that received sustained national coverage, first on the web and then in the media. While there were attempts at cover-ups, and ultimately coverage was limited, the public was exposed to a full two months of coverage in the national media, particularly on television (Tilt and Xiao 2010). This was the first such environmental 
disaster with national coverage, and its impact on the Chinese public was similar to the Exxon Valdez oil spill in the United States in 1987-a notable jump in environmental awareness and demands for greater action. The actual incident involved a fire at a petrochemical plant owned and operated by PetroChina, the world's sixth largest company, ${ }^{9}$ and a major economic and political power in China. The fire caused the release of several chemicals, including benzene and nitrobenzene, into the Songhua River near Jilin, upstream of the major city of Harbin, and contaminated river water that flowed into the Heilongjiang or Amur River, causing concern on both sides of the Sino-Russian border (UNEP 2005).

The government's immediate response included two forms of damage control. The first was to address the pollutants in the river. The second was on the public relations front, and specifically to address the public's concern that someone be held responsible. The official fingered was China's top environmental enforcement official, then SEPA administrator Xie Zhenhua, who resigned. While much domestic and international media attention focused on the failure of Xie's agency to enforce environmental regulations at the PetroChina plant, it seems unlikely that anyone in the government leadership actually thought that Xie's subministerial body had the power to enforce regulations at one of the world's largest companies, whose leadership far outranked him in the CCP hierarchy. More likely, Xie took a fall for the team. Indeed he appears to have been rewarded for doing so: he came back to government the following year with full ministerial rank, responsible for climate change in the National Development and Reform Commission. ${ }^{10}$

Ultimately, the response to the spill helped SEPA build momentum for much greater change-setting and achieving clear goals in the Five Year Plan process and gaining greater enforcement authority. The two critical breakthroughs in environmental enforcement in the last decade have been the goal setting process in the 1lth Five Year Plan (2006-2010) and the elevation of SEPA to ministerial level-the Ministry of Environmental Protection (MEP) - in 2007. Environmental goals had been part of previous Five Year Plans, but the targets set had never been met. SEPA took a new tack in the 1lth Five Year Plan. Instead of setting a large number of goals and then failing to meet them, they chose just two goals-one air pollutant and one water pollution measurement-and focused all efforts on these. This was a novel approach-most developed countries use a combination of human health and ecosystem health factors to set standards, and the recommendations from the WHO, for example, are entirely based on human health. The 1lth Five Year Plan targets were much more pragmatic. No one would suggest that reducing $\mathrm{SO}_{2}$ and chemical oxygen demand (COD) by 10 percent was sufficient, but achieving it was difficult in five years, and for the first time, the goals were actually met. ${ }^{11}$

The next watershed event in China's growing environmental awareness and institutional confidence was the 2008 Beijing Olympics. In bidding for the Games in 2001, Beijing promised an ambitious program to clean the air, and despite international skepticism leading up to the Games it largely 
delivered. After a very difficult first two days of the Olympics, with extreme heat, humidity, and air pollution, the regional governments came up with a mix of control measures that ensured remarkably good air quality for the rest of the Olympiad period, which included the Olympics and the Paralympics (Wang et al. 2009). ${ }^{12}$ The cleaner air was a result of long-term efforts-air quality slowly improved over the several years leading up to the Games-and a set of specific measures to guarantee well above-average performance during the Games. The most well-known measure was the imposition of odd and even driving days, but at least equally important were the reduction in power plant operations by 30 percent and the imposition of restrictions not just on the city of Beijing, but on the other provinces within the Beijing airshed. ${ }^{13}$

Critics at the time doubted the impact of short-term measures given that they by definition would not continue beyond the Olympics themselves. However, the positive impact of those measures added to subsequent pressure to continue to address air pollution issues. The public, and indeed government officials themselves became aware of what an improvement in air quality meant to quality of life. The most immediate public pressure was to continue to restrict driving, since the majority of Beijing's residents are not well-heeled drivers, but public transport and bicycle riders of more modest means who appreciate less crowded streets. The Beijing government initially planned to discontinue driving restrictions after the Games, but public outcry pushed them to modify the plan. The restriction was loosened from oddeven to a one-day-a-week restriction, ${ }^{14}$ and the government began actively seeking additional vehicle restriction measures. Since then, Beijing has instituted substantially higher parking fees, kept public transportation prices low and, most recently, has begun to restrict vehicle license plates (Pugliese 2011).

The advances made during the 1lth Five Year Plan period-reductions in $\mathrm{SO}_{2}$ and $\mathrm{COD}$ as well as the overall improvement in air quality demonstrated during the Beijing Olympics-combined with the MEP's new bureaucratic heft as a full ministry enabled it to propose more ambitious goals in the 12th Five Year Plan. In addition to continuing to reduce both $\mathrm{SO}_{2}$ and COD, the new plan added targets for an additional air pollutant, nitrogen oxides (NOx) and an additional water pollutant (ammonia nitrogen) (Seligsohn and Hsu 2011). At the same time, MEP was establishing a new regulatory mechanism for Regional Air Quality (RAQ) control (PRC 2010). Air pollution experts, including those within the SEPA and then MEP bureaucracy, knew full well that serious air pollution control efforts would require a focus on entire regions and not just on major cities. But that level of political coordination is difficult in a country in which most mandates are delegated to the provinces. The Beijing Olympics demonstrated the importance and effectiveness of regional control efforts, and enabled MEP to make the case to the State Council.

RAQ control is more complex than the types of emission standards MEP has enforced to date. Environmental regulations involve a complex mix of 
regulatory standards tied to outcomes - total emission loads allowed for various periods - hourly, daily, or yearly — with specific standards for sourcestechnology and emission requirements for automobiles, industrial users, and electric power plants, for example. ${ }^{15}$ Given that both the meteorology and the number and type of sources vary by region, to achieve any specific environmental outcome in densely populated, heavily industrial or meteorologically challenging areas requires adjustments to the types of restrictions on sources.

In addition to regulatory limits and standards, there have also been the Five Year Plan goals, which are focused on making progress to achieve certain percentage reductions rather than on specific environmentally determined outcomes. Given the size of the challenge, the Five Year Plans are a realistic way to move forward, but public frustration has grown, as pollution continues to be a major health and quality of life issue.

RAQ management is a major step forward in tying environmental enforcement to environmental outcomes, but it is not easy to implement. MEP needs to add a number of pollutants to its control strategy to address some of the largest health risks, to monitor and measure these effectively, and then to adjust controls to deal with variable conditions on the ground.

As MEP was in the midst of the spadework for implementing the RAQ regulations, public outcry again propelled their efforts forward. In the autumn of 2011, the Chinese blogosphere lit up with criticism of Beijing air quality, and shortly thereafter the domestic press joined the chorus. The trigger for the discussion was in part the poor air quality in the autumn. It may also have been articles in the international press commenting on the poor air quality measured at a monitor set up at the US Embassy that is transmitted via twitter. They were translated and shared on the Chinese Internet. The public outcry very much focused on Beijing. Thanks to a combination of the types of pollution sources in the area and Beijing's difficult meteorology, its air quality is markedly poorer than in other wealthy areas such as Shanghai and Guangdong.

While Beijing city's initial response was quite defensive, MEP was, in fact, well positioned to be responsive. Its annual meeting on RAQ management in November 2011 focused specifically on adding control of the additional pollutants that were needed to address the air quality problems. The focus at the time was on getting initial regulations in place within a year, and national level controls on PM 2.5 by $2016 .{ }^{16}$ Over the next several months, implementation sped up, and there are indications that nationwide PM 2.5 monitoring is moving forward. ${ }^{17}$ Beijing also announced much more ambitious targets than the national plan, promising to reduce air pollution by 15 percent by 2015 and 30 percent by 2020 (Reuters 2012).

Public concern about water quality has also grown, although public attention has been more sporadic. Air pollution is a near constant concern for urban residents, whereas much water pollution is invisible to the vocal urban 
public until a crisis occurs. The Songhua River was not the only such crisis in recent years. Two major algal blooms have attracted national attention-in Tai Lake north of Shanghai in 2007 (Goldkorn 2007) and at the Olympic sailing course in Qingdao in 2008 (Yardley 2008). Algal blooms are symptomatic of eutrophication, and there continue to be such blooms, including in both these locations with somewhat less national attention. As a result of the concern over eutrophication ammonia, nitrogen was added as a target in the 12th Five Year Plan. This is a critical step forward, but the challenges overall are even greater than in addressing air pollution.

\section{Climate change as a Driver}

Concern about energy security, economic health, and a better quality of life by reducing local air pollution have clearly driven much of China's actions, but climate change itself is clearly part of China's concerns. The complexity is that the climate change discussion began not so much as a discussion of the impacts of climate change on China's economy and development, but as a discussion of the costs of mitigation on China's future development. ${ }^{18}$ Thus, if we look back to the 1990s, the climate negotiations were seen mainly in terms of how to reduce the cost of engaging with the process. To not engage seemed risky, given that China's major trading partners were all engaged, but the process itself seemed to offer few benefits, especially given the time horizon of needs in a poor developed country. With poverty reduction as an immediate concern and the ambition to become a stronger nation, the Chinese government appeared less concerned about problems that at that time were predicted to be decades or even centuries in the future.

With climate change itself appearing much more remote then than it does now, technology transfer became an important issue. If solving the problem was not a sufficient carrot, perhaps offering a development benefit that should also help solve the problem might be useful. The challenge is that technology transfer has since been a major sticking point with China, as well as other developing countries arguing that they have not seen major transfers of technology. This is in part a definitional issue, since developing countries would like to see governments transfer technology, which has not happened under the United Nations Framework Convention on Climate Change (UNFCCC) or the Kyoto Protocol. At the same time, the Clean Development Mechanism (CDM), a program specifically designed to spur new technologies, has been well received and widely used in China. While not all projects have had cutting-edge technology, CDM financing has been critical to such new industries as wind power and important in spurring businesses that may not be cutting edge, but were new to China, such as waste to energy. ${ }^{19}$ In creating new energy industries and a whole commercial network to support the CDM market, the CDM created new groups of domestic stakeholders for a climate regime.

The publication of the Intergovernmental Panel on Climate Change's (IPCC) Fourth Assessment in February 2007 (IPCC 2007) marked another 
turning point in China's climate change awareness. While climate skepticism of the sort found in the United States has had a much smaller influence in China, prior to the Fourth Assessment there were doubts in the policy community that climate change would be all bad for China. If one goes back to the Third Assessment (IPCC 2001), there was very little in the way of quality modeling to make predictions at mid-latitudes. Some research had even suggested that $\mathrm{CO}_{2}$ might "fertilize" crops, increasing agricultural output. The research that fed into the Fourth Assessment suggested that any such effect would be outweighed considerably by changes in weather systems. Overall, China could expect more droughts in the North and floods in the South, both diminishing agricultural yields, as well as leading to other hardships and losses.

Not only did the Fourth Assessment speak more directly to how China would fare, but for the first time, significant numbers of Chinese researchers were involved in the effort as well. At least 10 percent of the coauthors were Chinese, including Qin Dahe, who headed the Chinese Meteorological Administration and was cochair of the Science Working Group within the IPCC. Even before the report was published, these researchers were presenting their findings to Chinese policy makers. As a result, there was a substantial shift in perspective within China on the extent of the risk of climate change itself, rather than the cost of mitigation. This focus has actually been heightened by the growing discussion of climate security as an international issue. In particular, the United States Defense Department's October 2003 report, "An Abrupt Climate Change Scenario and Its Implications for United States National Security" (Schwartz and Randall 2003), was highly influential in bringing home to the Chinese foreign policy establishment the security implications of climate change. ${ }^{20}$

The complexity for international observers, and especially for negotiating partners, is that the recognition of a national interest in climate mitigation is not one and the same as a commitment to any particular level of domestic mitigation. In fact, it raises the level of frustration within China at the failure of developed countries to act more rapidly after the signing of the 1992 Framework Convention (United Nations 1992), whose text specifically tasks developed countries with "taking the lead" at a time when Chinese emissions were a tiny fraction of what they are today.

Because of the global nature of climate change mitigation and its impacts, there is still a sense of a prisoner's dilemma in who should move first. In fact, the Chinese have moved farther toward seeing mitigation as in their own interest than have the United States. ${ }^{21}$ The Chinese also see the range of technologies they have been able to develop and deploy, in particular wind, solar, and nuclear power, as giving them a comparative advantage in the future. Chinese policy makers recognize the positive energy security, economic, and local environmental benefits of most climate mitigation actions-at least up to a point. The question really becomes how to justify actions that are more expensive than those other benefits might call for. 


\section{Adding it up: A NeW view of Development}

China remains a developing country with a per capita GDP still less than $\$ 5,000 .{ }^{22}$ Thus, development remains the critical domestic policy goal. However, the definition of what development means has changed fundamentally in the past decade. A decade ago, the only real measure was GDP. Today, public health, attractive cities, technological development, long-term sustainability have all become critically important. While China's per capita GDP is modest in global terms, it is dramatically higher than a decade or two ago. The result has been a rapid growth both in public expectations and in policy makers' and leaders' confidence in the ability of government to meet those expectations. Institutions are more sophisticated, and there is a great deal more confidence in these institutions.

At the same time, environmental issues have become recognized as important for energy and national security. Thus, in addition to the solid developmental reasons for supporting better environmental performance, China's leaders now recognize the importance of energy and climate security in existential terms.

Neither of these conclusions suggests that China is willing to go it alone on climate mitigation. Negotiations involve a complex set of considerations of what other countries can offer, and the Chinese are increasingly concerned about how much is offered from the non-EU developed world. It does suggest that China has its own national interest in these issues, and that it will continue to implement energy and environmental policies that align with what it defines as a national interest in sustainability.

Finally, the link to health outcomes continues to be tenuous. While there is good science suggesting that any reduction in pollution levels will achieve some positive health outcomes and thus all reductions should be welcomed, the goals set in the Five Year Plans are not tied to any specific intended health outcomes. Targets are set either in terms of absolute emissions numbers or as percentage reductions, and these are not tied to variations in how these numbers might affect vulnerable populations-variation in proximity, meteorology, geography, etc.

Thus, while the environment has clearly become a part of China's development agenda, there is still considerable scope for augmenting this focus and developing policies addressing specific goals, whether they be human health, ecosystem health, or other quality of life measures.

\section{Notes}

1. Growth rates either from China's own National Bureau of Statistics or the World Bank record these levels.

2. See the World Bank (1997) for an early comprehensive evaluation of China's environmental challenges. Also see SEPA's and now MEP's annual “The State of the Environment" reports for an annual appraisal of China's challenges for the last 13 years.

3. See for example Zhang et al. (2010). 
4. The country profile for China does not provide a definition for all the environmental factors included in the total number, but the WHO's accounting of environmental health is quite broad and includes occupational health, housing quality, transport-related accidents, and natural disasters. See Kay et al. (2000).

5. Indicators reported in 12th Five Year Plan.

6. There were some clear exemptions, such as the elimination of the energy efficiency bureaucracy, and over the course of the last decade some bureaucracies have been rebuilt.

7. A full chronology of the SARS epidemic is available at www.who.int/csr/ don/2003_07_04/en/, Hu's and Wen's dates for assuming office are at www.indexmundi.com/china/government_profile.html. The full National People's Congress was March 5-18, 2003.

8. Obviously there were political and foreign policy goals, as well, but development policy was focused on very direct economic issues. For a discussion of priorities under Jiang Zemin and Zhu Rongji, see Dittmer (2003).

9. PetroChina is ranked below Shell, Exxon, BP, and Sinopec (China's other large integrated oil company) in Fortune's Global 500.

10. Xie himself has been internationally recognized as an environmentalist, receiving the United Nation's Sasakawa Environment Prize in 2003.

11. 12th Economic and Social Development Plan of the People's Republic of China, March 2011. See Litao Wang et al. (2010) for a discussion of implementation in the 10th and 11th Five Year Plans and modeled results.

12. Yuxuan Wang et al. (2009) show reductions in ozone levels. Witte et al. (2009) show significant decreases in nitrogen oxides and carbon monoxide. Wentao Wang et al. (2009) document reductions in particulates during the Games, and a continued reduction afterwards.

13. Ibid.

14. Xin (2009) explains the post-Olympics policy, which continues in place.

15. They can also include cap and trade programs, such as the sulfur trading program in the United States, but it is important to remember that the sulfur trading program for acid rain is built on top of local emissions controls to deal with local human and environmental health standards. In China to date, there have been only limited attempts at trading.

16. PM 2.5 are particle matters in the air with a diameter of no more than 2.5 micrometers.

17. The China Daily headline of February 21, 2012, read "PM 2.5 to be Monitored Nationwide," www.chinadaily.com.cn/usa/china/2012-02/21/ content_14660835.htm; however the article gave no date. Importantly it discussed how Chinese Center for Disease Control and Prevention plans to link the data to health data, a major gap in how data is used in China.

18. Interviews with key government advisors, including Professors He Jiankun and Zou Ji, 2008. The priority on development costs is also highlighted by Lewis (2007).

19. Lewis (2010) describes the importance of CDM in promoting renewable energy in China, but also documents that the largest number of projects are in hydropower. While these projects may be additional, the technology certainly is not new to China.

20. I am grateful to Professor Zhang Haibin of Peking University for this chronology. He discussed the Department of Defense (DOD) report in an August 2011 talk at the United Nations office in Beijing. 
21. US opinion is of course quite varied and the Obama administration advocates a much stronger climate mitigation policy than the United States currently has. However, as a nation, the United States does not have a national climate law.

22. World Bank 2010 data: China's per capita GDP in current US dollars is $\$ 4,428$.

\section{REFERENCES}

Andrews-Speed, Philip and Roland Dannreuther. 2011. China Oil and Global Politics. London and New York: Routledge.

Bekedam, Henk. 2003. Speech at the International Forum on SARS Prevention and Control. Beijing, December 15-16. www.wpro.who.int/china/media_centre/ speeches/speech_20031215.htm.

Branstetter, Lee G. and Nicholas Lardy. 2006. "China's Embrace of Globalization." Department of Social and Decision Sciences, Carnegie Mellon University. Paper 49. http://repository.cmu.edu/sds/49.

Brandt, Loren and Thomas G. Rawski. 2008. "China's Great Economic Transformation." In China's Great Economic Transformation. Brandt and Rawski (eds.). Cambridge: Cambridge University Press.

Calder, Kent E. 2005. China's Energy Diplomacy and Its Geopolitical Implications. Edwin O. Reischauer Center for East Asian Studies, Johns Hopkins SAIS.

Chan Lai-Ha, Lucy Chen, and Jin Xu. 2010. China's Engagement with Global Health Diplomacy: Was SARS a Watershed? PLoS Medicine 7(4): e1000266.

Dittmer, Lowell. 2003. "Leadership Change and Chinese Political Development." The China Quarterly 176: 903-925.

Dollar, David and Aart Kraay. 2003. "Institutions, Trade, and Growth.” Journal of Monetary Economics 50(1):133-162.

French, Howard W. 2008. "Severe Snowstorms Batter China." New York Times, January 28. www.nytimes.com/2008/01/28/world/asia/28ihtchina.1.9543336.html.

Goldkorn, Jeremy. 2007. “Taihu Lake Pollution: Net Frenzy and Government Response." Danwei, June 1. www.danwei.org/bbs/taihu_lake_pollution_the_ inter.php.

Health Effects Institute (HEI). 2010. Outdoor Air Pollution and Health in the Developing Countries of Asia: A Comprehensive Review. Special Report 18. Boston, MA.

Intergovernmental Panel on Climate Change (IPCC). 2001. Climate Change 2001IPCC Third Assessment Report. Geneva, Switzerland: IPPC.

- 2007. Climate Change 2007: Synthesis Report. R. K. Pachauri and A. Reisinger (eds.). Geneva, Switzerland: IPPC.

Kay, David, Annette Pruess, and Carlos Corvalan. 2000. Methodology for Assessment of Environmental Burden of Disease. Geneva: World Health Organization.

Lewis, Joanna I. 2007. "China's Strategic Priorities in International Climate Change Negotiations.” The Washington Quarterly 31(1):155-174.

- 2010. "The Evolving Role of Carbon Finance in Promoting Renewable Energy Development in China.” Energy Policy 38(6):2875-2886.

Liu, Tianfu. 2006. "Pollution of the Songhua River: A Catalyst for Environmental Reform." China Law and Practice 20(2):66. 
Naughton, Barry. 2005. The New Common Economic Program: China's Eleventh Five Year Plan and What It Means. China Leadership Monitor, No. 16. Hoover Institution Stanford University.

- 2008. "A Political Economy of China's Economic Transition." In China's Great Economic Transformation. Loren Brandt and Thomas G. Rawski (eds.). Cambridge: Cambridge University Press.

People's Republic of China (PRC). 2010. Notice of the General Office of the State Council about Forwarding Guiding Opinions on Pushing Forward the Joint Prevention and Control of Atmospheric Pollution to Improve the Regional Air Quality Developed by the Ministry of Environment Protection and Relevant Departments. No. 33 of the General Office of the State Council. Original at http://zfs.mep.gov.cn/fg/gwyw/201005/t20100514_189497.htm; translation at www.chinafaqs.org/files/chinainfo/ChinaFAQs_Joint_Prevention_and_ Control_of_Atmospheric_Pollution_by_State_Council_translated.pdf.

Pugliese, Tony. 2011. “CHINA: Beijing Drastically Limits New Vehicle Registrations in 2011." Just-Auto, January 4. www.just-auto.com/news/beijing-drasticallylimits-new-vehicle-registrations-in-2011_id108230.aspx.

Ravallion, Martin and Shaohua Chen. 2005. Fighting Poverty: Findings and Lessons from China's Success. The World Bank, http://go.worldbank.org/ QXOQI9MP30.

Reuters. 2012. "Beijing to Cut Air Pollution by 15 Percent by 2015." February 9. www.reuters.com/article/2012/02/09/us-china-beijing-pollutionidUSTRE8180C520120209.

Schwartz, Peter and Doug Randall. 2003. "An Abrupt Climate Change Scenario and Its Implications for United States National Security." Washington, DC: US Department of Defense.

Seligsohn, Deborah and Angel Hsu. 2011. "How Does China's 12th Five-Year Plan Address Energy and the Environment?" ChinaFAQs, March 7. www.chinafaqs. org/blog-posts/how-does-chinas-12th-five-year-plan-address-energy-andenvironment.

Shirk, Susan L. (ed.). 2010. Changing Media, Changing China. New York: Oxford University Press.

Smith, Kirk R. 2008. "Comparative Environmental Health Assessments.” Annals of the New York Academy of Sciences 1140:31-39.

Tilt, Bryan and Qing Xiao. 2010. "Media Coverage of Environmental Pollution in the People's Republic of China: Responsibility, Cover-Up and State Control.” Media Culture \& Society 32(2):225-245.

United Nations. 1992. United Nations Framework Convention On Climate Change.

United Nations Environment Programme (UNEP). 2005. The Songhua River Spill China, December 2005, Field Mission Report. New York: United Nations.

Wang, Litao, Carey Jang, Yang Zhang, Kai Wang, Qiang Zhang, David Streets, Joshua Fu, Yu Lei, Jeremy Schreifels, Kebin He, Jiming Hao, Yun-Fat Lam, Jerry Lin, Nicholas Meskhidze, Scott Voorhees, Dale Evarts, and Sharon Phillips. 2010. "Assessment of Air Quality Benefits from National Air Pollution Control Policies in China." Atmospheric Environment 44(28):3442-3448.

Wang, Wentao, Toby Primbs, Shu Tao, and Staci L. Massey Simonich. 2009. "Atmospheric Particulate Matter Pollution during the 2008 Beijing Olympics." Environmental Science \& Technology 43(14):5314-5320. 
Wang, Yuxuan, Jiming Hao, Michael B. McElroy, J. William Munger, Hong Ma, Dan Chen, and Chris P. Nielsen. 2009. "Ozone Air Quality during the 2008 Beijing Olympics: Effectiveness of Emission Restrictions." Atmospheric Chemistry and Physics 9:5237-5251.

Witte, J. C., M. R. Schoeberl, A. R. Douglass, J. F. Gleason, N. A. Krotkov, J. C. Gille, K. E. Pickering, and N. Livesey. 2009. "Satellite Observations of Changes in Air Quality during the 2008 Beijing Olympics and Paralympics." Geophysical Research Letters 36:L17803.

Wong, Christine. 2009. "The New Social and Economic Order in TwentyFirst Century China: Can the Government Bring a Kinder, Gentler Mode of Development?" In Global Giant, Is China Changing the Rules of the Game? Eva Paus, Penelope B. Prime, and Jon Western (eds.). New York and London: Palgrave Macmillan.

World Bank. 1997. Clear Water, Blue Skies: China's Environment in the Next Century. China 2020 Series. Washington, DC: World Bank.

Xin, Dingding. 2009. "Beijing Car Restrictions to Continue.” China Daily, April 6. www.chinadaily.com.cn/bizchina/2009-04/06/content_7651378.htm.

Yardley, Jim. 2008. "To Save Olympic Sailing Races, China Fights Algae.” New York Times, July 1. www.nytimes.com/2008/07/01/world/asia/0lalgae.html.

Zhang, Junfeng, Denise L. Mauzerall, Tong Zhu, Song Liang, Majid Ezzati, and Justin V. Remais. 2010. "Environmental Health in China: Progress towards Clean Air and Safe Water.” The Lancet 375(9720):1110-1119. 